\title{
JERZY PIETRKIEWICZ — JAN BOLESŁAW OŻÓG. KORESPONDENCYJNY DIALOG AUTENTYSTÓW (1937-1988)
}

\author{
Rafał MOCZKODAN (Uniwersytet Mikołaja Kopernika, Toruń) \\ ORCID: 0000-0003-1287-2888
}

Jerzego Pietrkiewicza (ur. 1916) i Jana Bolesława Ożoga (ur. 1913) połączyła przyjaźń poetycka lat młodzieńczych, gdy obaj należeli do założonej przez Stanisława Czernika ${ }^{1}$ w połowie lat $30 . \mathrm{XX}$ wieku grupy autentystów. Przypomnijmy skrótowo, że współtworzyli ją — obok trzech wymienionych — Tadeusz Juliusz Demczyk ${ }^{2}$, Józef Andrzej Frasik $^{3}$, Czesław Janczarski ${ }^{4}$, Bolesław Kobrzyński ${ }^{5}$, Stefan Szajdak ${ }^{6}$ Głosząc prymat

\footnotetext{
${ }^{1}$ Stanisław Czernik (1899-1969), poeta, prozaik, badacz folkloru, główny teoretyk autentyzmu. Pochodził z rodziny chłopskiej, absolwent ekonomii Uniwersytetu Poznańskiego (1925). W latach 1935-1939 wydawał w Ostrzeszowie, gdzie pracował jako nauczyciel, miesięcznik „Okolica Poetów". Uczestnik kampanii wrześniowej 1939, po wojnie mieszkał i tworzył w Warszawie, a następnie w Łodzi (od 1960 r. redaktor naczelny Wydawnictwa Łódzkiego). Przed wojną drukował m.in. w „Kurierze Literacko-Naukowym”, „Kulturze”, „Kamenie”, „Prosto z Mostu”.

${ }^{2}$ Tadeusz Juliusz Demczyk (1908-1942), poeta. Autor m.in. zbiorów wierszy Wichry republikańskie, Sercem na przestrzat, Tworzę życiorys.

${ }^{3}$ Józef Andrzej Frasik (1910-1983), poeta. Pochodził z rodziny chłopskiej, absolwent filologii polskiej na Uniwersytecie Jagiellońskim (1937), uczestnik kampanii wrześniowej 1939, w latach 1945-1947 członek komitetu redakcyjnego tygodnika „Wieś”, wieloletni współpracownik Polskiego Radia w Krakowie. Przed wojną drukował m.in. w „Kurierze Literacko-Naukowym”, „Ilustrowanym Kurierze Codziennym”, „Czasie”, „Pionie”.

${ }^{4}$ Czesław Janczarski (1911-1971), poeta, autor książek dla dzieci. Absolwent filologii polskiej na Uniwersytecie Warszawskim, obok autentystów związany literacko także z Józefem Czechowiczem. Po wojnie skupiony na twórczości dla dzieci, od 1957 r. redaktor naczelny czasopisma „Miś”, od 1960 r. w redakcji „Świerszczyka”. Drukował m.in. w czasopismach dla dzieci: „Mały Płomyczek”, „Płomyczek”, „Świerszczyk”, „Przyjaciel Dzieci”.

${ }^{5}$ Bolesław Kobrzyński (1914-1986), poeta. Pochodził z rodziny górniczo-chłopskiej, absolwent Seminarium Nauczycielskiego w Wągrowcu. Debiutował w „Okolicy Poetów” w 1938 r.
} 
prawdy przeżycia zapisywanego w literackim świadectwie, autentyści podporządkowali mu formę ${ }^{7}$, co — w ostatecznym rozrachunku — przełożyło się na odrzucenie kreacjonistycznej, ambitnej liryki i zamknęło twórców w mechanistyczno-deterministycznej wizji ludzkiego losu. Wywodzący się ze środowisk chłopskich, pochwalający prostotę i pierwotność warunków życia wiejskiego, ograniczyli listę tematów, negowali rolę fantazji i wyobraźni, wprowadzając zamiast nich „,fantazjotwórstwo”, czyli świadome łączenie dwóch odrębnych elementów przeżycia osobistego w jeden poetycki obraz $^{8}$. W efekcie program poetycki przekształcił się w światopogląd, któremu część twórców tej grupy — w tym Jan Bolesław Ożóg i częściowo Jerzy Pietrkiewicz pozostali wierni latami. Jak pisał Stanisław Czernik:

Rozległość pojęcia autentyzmu przekracza właściwie granice poezji. Obejmuje wszystkie dziedziny sztuki i życia. Autentyzm nie jest więc wyłącznym, sztucznie wyhodowanym kierunkiem poetyckim, lecz wyrazem światopoglądu. Jakiego? Oto pytanie, które powinno nas zaniepokoić. Można odpowiedzieć — światopoglądu powstającego 9 .

Dojrzewających artystycznie twórców rozdzieliła druga wojna światowa. Jerzy Pietrkiewicz (1916-2007) w 1939 roku przedostał się przez Rumunię do Francji, a po jej upadku w 1940 roku do Wielkiej Brytanii. Nieprzyjęty do armii polskiej ze względu na stan zdrowia, został skierowany na studia i od 1941 roku studiował filologię angielską na St. Andrews University w Glasgow. Włączył się w życie literackie emigracji niepodległościowej, drukując m.in. w takich pismach, jak „Jestem Polakiem”, „Dziennik Żołnierza”, „Myśl Polska”, „Skrzydła”, a później także w paryskiej „Kulturze” i londyńskich „Wiadomościach”. Z czasem zaczął także współpracę z innymi periodykami, m.in. „The Slavonic and East European Review”, „Encounter”, „The Twentieth Century”, „Canadian Slavonic Papers”, „Times Literary Supplement”. W 1947 roku uzyskał stopień doktora za pracę porównawczą o formach liryki angielskiej i polskiej i został zatrudniony w School of Slavonic and East European Studies w University of London, gdzie pracował do 1980 roku, gdy przeszedł na emeryturę. Po wojnie zarzucił twórczość poetycką, a od 1951 roku zaczął publikować powieści po angielsku. Ogłaszał je pod nazwiskiem Jerzy Peterkiewicz — zmieniona forma była łatwiejsza do wymówienia dla czytelników anglojęzycznych. Oprócz tego ogłosił też szereg studiów i szkiców o literaturze polskiej i angielskiej, opracował antologie poezji, był oficjalnym tłumaczem wierszy Jana Pawła II na język angielski.

Z kolei Jan Bolesław Ożóg (1913-1991), który w 1939 roku uzyskał absolutorium na Uniwersytecie Jagiellońskim w Krakowie (fillologia polska), wojnę spędził w Nienadówce, gdzie od 1943 roku włączył się w tajne nauczanie, prowadząc komplety licealne. W tym samym roku wstąpił do Armii Krajowej, następnie ukończył tajną podchorążówkę. Brał udział w walkach w powiecie kolbuszowskim, a w 1944 roku w okolicach Warszawy. W okresie okupacji nie zaprzestał działalności literackiej, drukując swoje teksty

Uczestnik kampanii wrześniowej 1939, następnie żołnierz 2. Korpusu (brał m.in. udział w bitwie o Monte Cassino). Od 1946 r. w Londynie, członek Związku Pisarzy Polskich na Obczyźnie, współpracował z wieloma emigracyjnymi czasopismami.

6 Stefan Szajdak (1910-2004), poeta. Absolwent Seminarium Nauczycielskiego w Ostrzeszowie. W latach 30. współtwórca grupy poetyckiej „Wołyń” (razem z Wacławem Iwaniukiem, Czesławem Janczarskim). W czasie wojny aresztowany przez NKWD i zesłany do łagru. Od 1947 r. pracował jako nauczyciel w Środzie Wielkopolskiej. Absolwent UAM (1967). Przed wojną drukował m.in. w „Kamenie”, „Kulturze”, „Kuźnicy”, „Prosto z Mostu”.

${ }^{7}$ Zob.: S. Czernik, Styl w liryce, Okolica Poetów 1935 nr 1, s. 3-6.

${ }^{8}$ Zob.: tenże, Fantazjotwórstwo poetyckie, Okolica Poetów $1935 \mathrm{nr} 4 / 5$, s. $2-5$.

${ }^{9}$ Tenże, Co i jak, Okolica Poetów 1936 nr 10, s. 2. 
m.in. w tajnych gazetkach „Na Posterunku”, „Oracz” oraz w krakowskim „Miesięczniku Literackim”. We wrześniu 1944 roku w Sokołowie Małopolskim współorganizował gimnazjum, w którym przez kilka miesięcy uczył języka polskiego. Kolejne pięć lat (19451950) pracował jako nauczyciel w Radomiu, po czym w 1950 roku zamieszkał w Krakowie, zaś do 1951 roku wykonywał tę samą pracę w Bochni. Wcześniej, w 1945 roku, wstąpił do ZZLP, a w 1946 roku uzyskał magisterium na UJ. Po zakończeniu pracy w Bochni poświęcił się wyłącznie twórczości literackiej. Współpracował m.in. z „Tygodnikiem Powszechnym”, „Odrą”, „Słowem Powszechnym”, „Poezją”, „Miesięcznikiem Literackim”. Otrzymał szereg nagród i odznaczeń państwowych.

Świadectwem przyjaźni Ożoga i Pietrkiewicza pozostają dwa, niestety zdekompletowane, zbiory listów. Pierwszy znajduje się w zbiorach Biblioteki Jagiellońskiej w Krakowie i wchodzi w skład archiwum prywatnego Jana Bolesława Ożoga. W nim to, w zbiorze korespondencji opatrzonej sygnaturą Przyb. 184/17 - T. 6: Pak - Pietruszkowa, odnajdujemy skoroszyt opisany: Pietrkiewicz (Peterkiewicz) Jerzy. Znajduje się tam piętnaście listów i jedenaście kart pocztowych Pietrkiewicza do Ożoga z okresu: jesień 1937-18 września 1987 r. Zbiór drugi znajduje się w toruńskim „Archiwum Emigracji” w archiwum prywatnym Jerzego Pietrkiewicza. Zbiór opatrzony sygnaturą AE/JP/CXLIV Korespondencja polska, osoby: $M-O$ zawiera teczkę Ożóg Jan Bolesław, w której znajdują się dwadzieścia dwa listy i siedem kart pocztowych Ożoga do Pietrkiewicza oraz dwa odpisy listów Pietrkiewicza do Ożoga z okresu: 18 października 1956-1 grudnia $1988^{10}$.

Już choćby porównanie dat granicznych obu zbiorów wskazuje, że są one dalekie od kompletności. Część listów zapewne nie została zachowana przez odbiorców, część — na co wskazują oni sami w korespondencji — nigdy do adresata nie dotarła. Dotyczy to szczególnie pierwszych lat powojennych (choć zdarzało się aż do lat 70.), w których obaj pisarze sygnalizowali problemy z przesyłkami pocztowymi czy paczkami, dopytywali o wcześniej wysłane listy. Nie ma uzasadnienia tworzenie pełnego rejestru tych fragmentów korespondencji, które wskazują na wymienione problemy, ograniczmy się zatem do kilku przykładów. W liście z 8 kwietnia 1948 roku Pietrkiewicz pisał: „Chciałbym ci przysłać mój ostatni tom Pogrzeb Europy ${ }^{11}$, w którym jest duży essay pt. Nowoczesność $w$ tradycji. Ale trudno stąd książki wysyłać"12. Podobnie w lipcu tego samego roku donosił: „Pisałem o Tobie w »Myśli Polskiej« kilka razy ${ }^{13}$ w związku z autentyzmem, ale niczego nie można, niestety przesłać" ${ }^{14}$. Z kolei w czerwcu 1970 roku notował:

Miałem głupie doświadczenia z pocztą. Rzeczy giną. Posłałem komuś książkę angielską dla dzieci (!), i nie doszła. Są widać ogromni idioci, którzy robią kulturze polskiej szkody, utrudniając naturalny obieg krwi. Cóż warta wymiana myśli bez możliwości przekazywania książek? Mówię Ci, to mnie czasem tak irytuje, że dziwię się sobie: dlaczego jeszcze przy sprawach polskich tkwię ${ }^{15}$.

\footnotetext{
${ }^{10}$ Wszystkie przywołane w tekście listy pochodzą z tych dwóch zbiorów.

${ }^{11}$ J. Pietrkiewicz, Pogrzeb Europy. Liryki. Poematy. Essay o poezji, Londyn 1946.

${ }^{12}$ List J. Pietrkiewicza do J. B. Ożoga z 8 kwietnia 1948.

${ }^{13}$ Zob. np.: J. Pietrkiewicz, Poezja ułatwiona. K. Wierzyńskiemu w odpowiedzi, Myśl Polska 1943 nr 58; tenże, Ultraista Borges z Argentyny, Myśl Polska 1948 nr 122.

${ }^{14}$ Karta pocztowa J. Pietrkiewicza do J. B. Ożoga z 3 lipca 1948.

${ }^{15}$ List J. Pietrkiewicza do J. B. Ożoga z 1 czerwca 1970.
} 
Biorąc pod uwagę opisane problemy, jak również to, że zestawione ze sobą oba zbiory korespondencji nie są wolne od luk, warto pokusić się o ich lekturę, scharakteryzować na ich podstawie relację łączącą dwóch poetów, zaobserwować zachodzące w niej na przestrzeni lat przemiany, zarejestrować główne tematy i problemy omawiane przez korespondentów.

Listy sprzed wojny zachowały się dwa - oba Pietrkiewicza do Ożoga. W tym nieprecyzyjnie datowanym na ,jesień 1937” autor Prowincji dziękował za list Ożoga „taki, jak zwykle miły i dobry. Twoja poezja taka sama jak list"16, po czym przechodził do omówienia aktualnych planów wyjazdowych (w tym zaplanowanej wizyty w Krakowie). Drugi, z początku 1939 roku, także otwierał serdecznym wyznaniem: „Czuję do Ciebie coraz więcej przyjaźni”, i dodawał: „Cieszę się, że Ty wchodzisz na coraz równiejszą drogę. Twoje ostatnie wiersze bardzo ciekawe"17. W obu listach Pietrkiewicz utyskiwał na swój pełen trudności pobyt w Warszawie. Pisał m.in.:

U mnie wszystko stare, ale walk sporo. Wszyscy czyhają, żeby tu mnie w Warszawie wykończyć. Przerażają ich moje poczynania literackie i bojowe artykuły. Ale radę sobie dam $^{18}$.

W poezji naszej dziwnie pusto i głupio. Ludzie się demobilizują i kołowacieją. Żydy i lewica otumania poczciwych [?] do reszty ${ }^{19}$. [... ] Ja tu w Warszawie staczam wielkie batalie, godzę ludzi, robię porozumienia, byle tylko nasza sprawa wygrała, a musi wygrać. Nie może $70 \%$ Polaków być odciętych od dóbr kulturalnych ${ }^{20}$.

Co ciekawe, choć narzekał na Warszawę i panujące w niej stosunki, to jednocześnie Pietrkiewicz zachęcał Ożoga, aby ten przeniósł się do stolicy: „A może kiedy do Warszawy spróbujesz się przeprowadzić? Tu łatwiej żyć. Tylko że Kraków to atmosfera. Może lepiej, że tam siedzisz. Jesteś bliżej wsi i szczerości"21.

Druga wojna światowa przerwała korespondencyjny dialog na kilka lat. Po jej zakończeniu najprawdopodobniej pierwszy odezwał się Ożóg. Niestety, list, o którym Pietrkiewicz wspomina w swojej odpowiedzi z 8 kwietnia 1948 roku, nie zachował się. Przebywający w Londynie poeta dziękował swojemu krakowskiemu przyjacielowi za książki, wspominał spotkania w Krakowie, po czym składał następującą deklarację:

${ }^{16}$ List J. Pietrkiewicza do J. B. Ożoga, jesień 1937.

${ }^{17}$ List J. Pietrkiewicza do J. B. Ożoga z 3 stycznia 1939.

${ }^{18}$ List J. Pietrkiewicza do J. B. Ożoga, jesień 1937.

19 Przed wojną Jerzy Pietrkiewicz był związany z ruchem nacjonalistycznym (współpracował, podobnie jak kilku jego kolegów z grupy autentystów, m.in. z „Prosto z Mostu” Stanisława Piaseckiego). Swoim antylewicowym i antysemickim poglądom dawał wyraz w publicystyce i korespondencji (przywołany list zakończył zwrotem: „Serdeczny polski i katolicki uścisk dłoni”). Po wojnie określił ten okres i obszar swojej działalności „dziennikarskimi bzdurami” (zob.: J. Pietrkiewicz, Na szali Losu. Autobiografia, przeł. A. Skarbińska-Zielińska, Warszawa 2016; por. K. Adamczyk, Doświadczenia polsko-żydowskie w literaturze emigracyjnej (1939-1980), Kraków 2008; tenże, Niedopowiedziany kontekst - Jerzy Pietrkiewicz, wspótpracownik „Prosto z mostu” $i$,Polski Zbrojnej”, [w:] Jerzy Pietrkiewicz. Inna wersja emigracji, red. B. Czarnecka, J. Kryszak, Torun 2000; B. Czarnecka, Wstęp, [w:] J. Pietrkiewicz, Dla pokrzepienia mózgów. Szkice literackie z lat 1940-1948. Nowoczesność w tradycji. Essay o poezji. Trust the trees, oprac. B. Czarnecka, Torun 2002).

${ }^{20}$ List J. Pietrkiewicza do J. B. Ożoga z 3 stycznia 1939.

${ }^{21}$ Tamże. 
Śledziłem Twoje wiersze w prasie, mawiając do siebie, że to jedyna poezja, którą warto czytać, bo zamyka się w emocjonalnym zasięgu liryki. I dlatego przyjemnie mi potwierdzić te opinie ciche słowami atramentowymi ${ }^{22}$.

Wypowiedź tę można uznać za dość charakterystyczną dla omawianego korespondencyjnego dialogu. $Z$ jednej bowiem strony zapoczątkowuje ona szereg komplementów, którymi obaj korespondenci będą się obdarzali w kolejnych listach, a z drugiej poprzedza ona jakąśs prośbę o charakterze literacko-zawodowym. To bardzo często pojawiający się wątek w tej korespondencji - poszukiwanie konkretnych publikacji, zabieganie o druk takiego czy innego tekstu po drugiej stronie żelaznej kurtyny, prośby o wsparcie działań promujących twórczość. I jakkolwiek poświęcone tym zagadnieniom fragmenty znacznie częściej pojawiać się będą w listach Ożoga, to jednak jako pierwszy tego typu prośbę sformułował Pietrkiewicz:

Słuchaj, kochany Janie B., czy może masz moje Wiersze i poematy ${ }^{23}$. Prowincję $e^{24}$ udało mi się z trudem wydostać. Ale tego dużego tomu nie mam. Przyślij mi go koniecznie jeśli masz lub wydobądź spod ziemi. Będę ogromnie wdzięczny. I odwzajemnię się jakimś prozaicznym prezentem. [...] Wiesz chyba co to znaczy nie mieć własnych utworów. Szewc bez butów chodzący...

Należy w tym miejscu odnotować, że autor Prowincji, który w 1951 roku odłoży na blisko trzydzieści lat poetyckie pióro, dzielił się jeszcze z krakowskim przyjacielem uwagami na temat - jego zdaniem najważniejszych — kierunków rozwoju poezji. Pisał m.in.:

Oczywiście i tutaj dużo jest literackiego zacofania, tak że trzeba walczyć piórem, bo cele poetyckie są przecież poza zgiełkiem doraźnej użyteczności. Rozwijajmy metaforę, przede wszystkim metaforę, a unikajmy muzyczności rzekomo folklorystycznej: wiersz dzisiejszy to problem konstrukcji od wewnątrz — to mnie głównie absorbuje. Możesz przez rezygnację $\mathrm{z}$ efektów zewnętrznych, a przez rozbudowanie wiersza od środka zwyciężyć w okresie nadużywania literatury do celów pozaliterackich ${ }^{25}$.

Moja poezja bardzo się zmieniła, ale wiernie stoję przy metaforze (którą tu na Zachodzie zajmują się i semantycy, i często poetyccy krytycy) ${ }^{26}$.

Te dwie uwagi stanowią jedyne świadectwo autorefleksji poetyckiej Pietrkiewicza zawartej $\mathrm{w}$ omawianym zbiorze korespondencji. W sposób naturalny wiązało się to z decyzją zmiany języka na angielski i porzucenia poezji na rzecz prozy. Co jednak znamienne, także wypowiadając się w latach późniejszych na temat twórczości krakowskiego przyjaciela, będzie Pietrkiewicz ją chwalił, jednak ograniczając się jedynie do ogólników. Nie znajdziemy w tej korespondencji analitycznych uwag na temat formy lub stylu, środków wyrazu lub tematyki. Zresztą Ożóg przyjmie dokładnie taką samą strategię. Co ciekawe, także twórczość innych kolegów po piórze nie będzie specjalnie mocno zaprzątała uwagi obu pisarzy. Rzucane od czasu do czasu drobne komentarze będą jednoznaczne, wyraziste, niepodbudowane jakąkolwiek analizą. Tak na przykład charakteryzował Pietrkiewicz poezję wczesnych lat powojennych:

\footnotetext{
${ }^{22}$ List J. Pietrkiewicza do J. B. Ożoga z 8 kwietnia 1948; tu nawiązanie do tego, że list został napisany piórem.

${ }_{23}^{23}$ J. Pietrkiewicz, Wiersze i poematy, Warszawa 1938.

${ }^{24}$ Tenże, Prowincja. Poemat, Warszawa 1936.

${ }^{25}$ Karta pocztowa J. Pietrkiewicza do J. B. Ożoga z 3 lipca 1948.

${ }^{26}$ List J. Pietrkiewicza do J. B. Ożoga z 8 kwietnia 1948.
} 
Oczywiście poezja nasza jest w stanie upadku, rzemiosło bez uprawy należytej: co za bzdury rymowane ten [Czesław] Miłosz i [Konstanty Ildefons] Gałczyński wypisują. Toż to prawdziwe wstecznictwo! A i [Stanisław] Piętak ${ }^{27}$ wkółko [!] gra na tę samą nutę. Poeci bez intelektualnych podstaw skazani są na zamieranie wyobraźni.

Nie wiem, czy czytasz listy [Cypriana Kamila] Norwida? Tam jest odpowiedź na tragedię pisarstwa naszego. Norwid to chyba największy liryk ostatnich pięciuset lat. Obok [Luisa de] Góngory ${ }^{28}$ jedyny konsekwentny artysta! ${ }^{29}$

Próba restytucji przedwojennej przyjaźni powiodła się częściowo. W drugiej połowie 1948 roku kontakt między poetami urwał się na kolejnych osiem lat. Rzecz jasna przyczyniły się do tego zmiany polityczno-kulturalne zachodzące w Polsce: blokowanie i utrudnianie kontaktów z twórcami zza żelaznej kurtyny (zarówno zachodnimi, jak i emigracyjnymi), wzmożona cenzura, narastająca presja na środowiska twórcze W związku z promowaniem socrealizmu. Dopiero przemiany związane z odwilżą 1956 roku sprawiły, że Ożóg zdecydował się na wznowienie kontaktu. Pierwszy list wysłał, gdy tylko to było możliwe — w połowie października.

Co interesujące, krakowski poeta przyjął w nim wręcz oficjalny ton. Choć jego wcześniejsze listy do londyńskiego przyjaciela się nie zachowały, to jednak na podstawie odpowiedzi zwrotnych, zaczynających się od słów: „Drogi Janku!”30 , „Kochany Janie Bolesławie”,31, „Drogi Janie Bolesławie”32, i utrzymanych w konwencji pisania per „ty”, możemy wnioskować, że i listy Ożoga były równie przyjacielskie i serdeczne. A ten z października 1956 roku zaczynał się od słów: „Drogi Panie Jerzy!” i był utrzymany w konwencji pisania per ,wy":

Bardzo Was pewnie zdziwi ten list z kraju. Przez osiem lat nie mogłem pisać. Ogromnie mnie ciekawi, co u Was słychać, co piszecie, co wydajecie. W Krakowie w Bibliotece Jagiellońskiej jest tylko jedna Wasza książka, zbiór opowiadań Umarli nie sa bezbron$n i^{33}$. Czytałem, rzecz ${ }^{34}$ interesująca. Próbowałem dotrzeć do „Myśli Polskiej”, ${ }^{35}$, ale znalazłem tylko kilka numerów ${ }^{36}$.

W dalszej części listu Ożóg pytał o możliwość otrzymania pism z artykułami, w których Pietrkiewicz pisał o nim (lub choćby o podanie danych bibliograficznych).

${ }^{27}$ Stanisław Piętak (1909-1964), poeta, prozaik, publicysta. Pochodził z rodziny chłopskiej, w latach 1929-1932 studiował filologię polską na Uniwersytecie Jagiellońskim, przerwał studia z powodów materialnych. W czasie wojny współpracował z polskim podziemiem (AK, Bataliony Chłopskie). Od 1945 r. w Łodzi aktywny działacz ZZLP, a od 1956 r. w Warszawie, gdzie kontynuował działalność pisarsko-redakcyjną. Przed wojną drukował m.in. w „Kurierze Literacko-Naukowym”, „Kamenie”, „Pionie”. Przez część badaczy jest łączony z grupą autentystów, inni wskazują, że pozostawał pod wyraźnym wpływem Awangardy Krakowskiej.

${ }^{28}$ Luis de Góngora y Argote (1561-1627), poeta hiszpański, jeden z głównych przedstawicieli baroku.

${ }^{29}$ List J. Pietrkiewicza do J. B. Ożoga z 8 kwietnia 1948. List kończy się zwrotem: „Trzymaj się autentycznej poezji. Dziękuję za pamięć. Uściski przyjaźni. Twój Jerzy P.”.

${ }^{30}$ List J. Pietrkiewicza do J. B. Ożoga z 3 stycznia 1939.

${ }^{31}$ List J. Pietrkiewicza do J. B. Ożoga z 8 kwietnia 1948.

${ }^{32}$ Karta pocztowa J. Pietrkiewicza do J. B. Ożoga z 3 lipca 1948.

33 J. Pietrkiewicz, Umarli nie sa bezbronni. Opowiadania z życia pod okupacja niemiecka, Glasgow 1943.

${ }^{34}$ Przekreślone słowo „książka”.

35 Pietrkiewicz z londyńskim dwutygodnikiem „Myśl Polska” współpracował w latach 1941-1945.

${ }^{36}$ List. J. B. Ożoga do J. Pietrkiewicza z 18 października 1956. 
Prosił także o zwrot dwóch rękopisów swoich wierszy, które miał wysłać do Londynu przed laty, oraz wyrażał zainteresowanie najnowszymi dokonaniami literackimi autora Prowincji.

Pietrkiewicz odpowiedział nieco mniej oficjalnie: „Drogi Panie - Janie Bolesławie", jednak o razu zastrzegł, że otrzymanych przed laty rękopisów raczej nie odnajdzie, a własnych tekstów drukowanych w czasopismach nie gromadzi. Odnosząc się do prośby o spis danych bibliograficznych, zastrzegł, że prześle, gdy go znajdzie, ale to i tak potrwa, a na komplement dotyczący zbioru opowiadań odpowiedział następująco: „Ten tomik moich nowel wart mało, pisane dla prasy wojennej, zbyt okolicznościowe",37.

Ożóg przyjął odpowiedź Pietrkiewicza za dobrą monetę: „Bardzo, bardzo wzruszył mnie list świąteczny. Cieszę się, że pamiętacie o starych »braciach w autentuźmie[!] «8 Doniosłem o tym przed kilku dniami [Stanisławowi] Czernikowi”. Następnie dzielił się z londyńskim poetą planami powołania nowego pisma, do współpracy z którym chciał go zaprosić. Co znamienne, w tym momencie ton listu ulega zmianie:

Prawdopodobnie uda mi się uzyskać zezwolenie na wydanie miesięcznika poetyckiego. Będzie on w moich założeniach służyć wszystkim poetom, głównie jednak sprawom autentyzmu (artykuły teoretyczne, wiersze, tłumaczenia, recenzje itp.). Mam nadzieję, że uda mi się namówić Pana, Drogi Jurku, do współpracy. Bardzo zależałoby mi także na uzyskaniu prac poetyckich innych pisarzy z emigracji, a przede wszystkim [Mariana] Czuchnowskiego ${ }^{39}$, [Wacława] Iwaniuka ${ }^{40}$ i [Bolesława] Kobrzyńskiego, niestety nie znam adresów.

List kończył się prośbą o pomoc $\mathrm{w}$ znalezieniu recenzenta Wierszy wybranych ${ }^{41}$, wysłanych przez Ożoga do londyńskich „Wiadomości”, ${ }^{\text {, }}$. W podobnym duchu utrzymany był list, który dotarł z Krakowa do Londynu na początku 1960 roku. Już bez wcześniej dostrzeganego dystansu Ożóg dzielił się radością z wydania zbioru opowiadan $^{43}$ i prosił Pietrkiewicza o pomoc w zainteresowaniu nim środowiska emigracyjnego. I choć oba te listy dzieli dystans dwóch lat, to wydaje się, że nie można tu mówić o kolejnej przerwie w kontakcie, gdyż na zawarte w liście z 1960 roku w post scriptum pytanie (,Wysyłałem poprzednio tomik poetycki Zielony wiatr ${ }^{44}$. Czy otrzymałeś?”) Jerzy Pietrkiewicz odpowiedział:

${ }^{37}$ List J. Pietrkiewicza do J. B. Ożoga z 16 listopada 1956.

${ }^{38}$ List J. B. Ożoga do J. Pietrkiewicza z 30 grudnia 1957.

${ }^{39}$ Marian Czuchnowski (1909-1991), poeta, prozaik, publicysta. Pochodził z rodziny chłopskiej, w 1928 roku rozpoczął studia na Uniwersytecie Jagiellońskim, które przerwał, aby po śmierci ojca objąć gospodarstwo we wsi Łużna pod Gorlicami. Był związany z poetami awangardowymi skupionymi wokół czasopisma „Linia”. Przed wojną zaangażował się w radykalny ruch robotniczo-chłopski, za co był kilkukrotnie aresztowany. W czasie wojny zesłany do łagrów w głąb ZSRR, ewakuował się w 1943 r. z Armią Polską na Bliski Wschód. Od 1944 r. w Londynie, gdzie łączył pracę fizyczną z twórczością literacką.

${ }_{40}$ Wacław Iwaniuk (1912-2001), poeta, krytyk literacki, thumacz. Pochodził z rodziny chłopskiej, absolwent Seminarium Nauczycielskiego w Chełmie (1934) i Wolnej Wszechnicy Polskiej w Warszawie (1939). W czasie drugiej wojny światowej żołnierz Armii Polskiej na Zachodzie (Francja, Anglia). Od 1948 r. w Kanadzie, gdzie łączył pracę zarobkową z twórczością literacką. Przed wojną drukował m.in. w: „Okolicy Poetów”, „Kamenie”, „Kurierze Porannym”, „Zwierciadle".

${ }^{41}$ J. B. Ożóg, Wiersze wybrane, Warszawa 1957.

${ }^{42}$ Zob.: Z. Zygma, Strofy do czytania, Wiadomości $1958 \mathrm{nr} 25$ (638), s. 10.

${ }^{43}$ J. B. Ożóg, Chustka. Opowiadania, Warszawa 1959.

${ }^{44}$ Tenże, Zielony wiatr, Kraków 1958. 
Serdeczne dzięki za miły list i za tom nowel, który mnie bardzo wzruszył. Zielony wiatr otrzymałem także i chyba odpisałem z podziękowaniami (czy list zaginął? — na ogół nie zbywam milczeniem takich przyjemnych okazji). [...]

Proza Twoja, miły Janie Bolesławie, wydaje mi się istotnie poetycka, ale nie lirycznie-mazgajska jak to u nas zwykle bywa: mogę jej dobitność ocenić lepiej pewnie [...] i dlatego cieszy mnie Twoja Chustka. Może dziś mój gust literacki nazbyt określony, ale Dziunek według mnie bije inne opowiadania na głowę. Ton w nim właściwy, jakiś swoiście subtelny układ zdarzeń i ludzi. [...] Jedna z najlepszych rzeczy jakie po polsku czytałem. Co nam w literaturze potrzeba, to właśnie tego rodzaju przemilczeń, niedomówień, wielostronności ludzkich reakcji, ale Boże-broń żadnych narzuconych uwag od autora, naklejek, doczepek etc. ${ }^{45}$

Odpowiedź Ożoga się nie zachowała. Można przypuszczać, że takich luk w dwóch zestawianych zbiorach listów jest więcej. Oto bowiem w kolejnym dostępnym, datowanym na 30 lipca 1963 roku, Pietrkiewicz zapewnia: „Autentycznie jestem w Polsce i przyjadę do Krakowa"46 (list wysłany z Ustronia Morskiego), i prosi o pomoc w zarezerwowaniu pokoju hotelowego na czas pobytu. W odpowiedzi ${ }^{47}$ Ożóg informował o dokonanej rezerwacji, ale i dopytywał o losy wysłanego kilka tygodni wcześniej listu „poprzedniego wraz z moją nową książką "48. Pietrkiewicz zareagował entuzjastycznie, dziękując za pomoc w zorganizowaniu noclegu, a do samego Ożoga zwracając się rozbudowaną apostrofą: „Mój Kochany Janku Bolesławie i Drogi w Autentyzmie Poeto z Bożej i Pogańskiej Łaski”, ${ }^{49}$. W podobnym tonie utrzymany był kolejny list, w którym Pietrkiewicz dziękował przyjacielowi za umilenie pobytu w Krakowie ${ }^{50}$.

Ton listów z lat 60. jest serdeczny i przyjacielski (rozpoczynają się one m.in. zwrotami: „Drogi Janku” — „Drogi Jerzyku”, „Drogi Jurku” — „Kochany Profesorze!”). I choć Pietrkiewicz nie wykazywał specjalnej aktywności w promowaniu twórczości krakowskiego poety, nie ustawał w komplementowaniu go w listach. Jak pisał w jednym z nich:

Dalej mi chodzą po głowie Twoje wiersze: dobra oznaka, żyją w pamięci.

Pamiętaj co Ci mówiłem na Plantach. Jako poeta masz przywileje w znaku We-

nus ${ }^{51}$ — miłość lubi poetów, kogóż powinna bardziej lubić?

Ale człowiek z przywilejem gwiazd i bogiń musi także kochać samego siebie -

tak jak bliźnich. Taki to morał poetycki. Czy jasno się wyrażam?

Mój Kochany, niech Ci Muza sprzyja dalej ${ }^{52}$.

Co ważne, w latach 60. coraz częściej w listach obu poetów pojawia się temat autentyzmu - promowania go, doceniania, podkreślania jego wartości. Oczywiście wcześniej obaj pisarze także przypisywali temu nurtowi poetyckiemu znaczącą wartość. Jeszcze przed drugą wojną światową, w niedługi czas po wydaniu - jak mu się zdawało — ostatniego numeru „Okolicy Poetów”, Jerzy Pietrkiewicz pisał: „„Okolica«

${ }^{45}$ List J. Pietrkiewicza do J. B. Ożoga z 28 lutego 1960.

${ }^{46}$ List J. Pietrkiewicza do J. B. Ożoga z 30 lipca 1963.

${ }^{47}$ List J. B. Ożoga do J. Pietrkiewicza z 3 sierpnia 1963.

${ }^{48}$ W 1963 roku Ożóg wydał dwie książki: J. B. Ożóg, Popiót mirtowy i inne opowiadania, Warszawa 1963; tegoż, W dzień, gdy noc, Kraków 1963.

${ }^{49}$ List J. Pietrkiewicza do J. B. Ożoga z 8 sierpnia 1963.

${ }^{50}$ List J. Pietrkiewicza do J. B. Ożoga z 27 sierpnia 1963.

${ }^{51}$ Odwołania do astrologii pojawiały się w korespondencji Pietrkiewicza z wieloma osobami, które darzył przyjaźnią. Zob.: J. Pietrkiewicz, Listy do redaktorów „Wiadomości”, oprac. i wstęp R. Moczkodan, Toruń 2017.

${ }_{52}$ List J. Pietrkiewicza do J. B. Ożoga z 27 sierpnia 1963. 
nie żyje ${ }^{53}$, ale i tak wiele dobrego zrobiła. Spełniła w i e $1 \mathrm{k}$ ą rolę w poezji polskiej ${ }^{54}$. Podobnie w pierwszym powojennym zachowanym liście donosił Ożogowi o czynionych przez siebie zabiegach przypominania autentyzmu szerszemu gronu odbiorców, z tym że po raz kolejny skarżył się na atmosferę i środowisko, w którym przyszło mu te zabiegi czynić. Pisał m.in.:

O Tobie i o autentyzmie pisałem tutaj, użerając się z naszą londyńską starszyzną literacką (wszystko co literackie cuchnie tu naftaliną!). Oni mnie także nie znoszą, ci naftaliniarze tradycjonalizmu źle pojętego, ale — na szczęście - mają respekt (a respekt ułatwia pracę) $)^{55}$.

Ogólna ocena autentyzmu, która wyłania się z zachowanej korespondencji, prowadzi do konkluzji, że zarówno Pietrkiewicz, jak i Ożóg uważali ten nurt literacki za najważniejsze osiągnięcie poezji polskiej. Krakowski poeta cieszył się, że jego londyński przyjaciel przypominał autentystów w swoich publikacjach, choć uważał, że nie jest to wystarczające. Pisał: „Przydałaby się w ogóle dobra, roztropna propaganda autentyzmu także w Anglii”, ${ }^{56}$.

Ożóg uważał, że o taką promocję winien zadbać Pietrkiewicz, który — jego zdaniem - z racji możliwości, które dawała mu praca na Uniwersytecie Londyńskim, powinien się bardziej w cały proces zaangażować. Dlatego w 1965 roku apelował:

Łaskawy i Drogi Przyjacielu!

Urwały się nasze kontakty, nie wiem, co wydajesz, co słychać u Ciebie. Proszę, napisz coś o sobie. [...]

Równocześnie z tym listem powinna dojść do Ciebie przesyłka z moją ostatnia książką poetycką ${ }^{57}$. Wiem, będziesz się nadal wymawiał, że nie przekładasz, błagam Cię jednak, zainteresuj tymi wierszami kogoś tam u Was, kto tłumaczy z poezji polskiej. Nie potrafię uwierzyć, że ważniejszy jest w literaturze angielskiej (przekładowczej [!]) np. jakiś zupełnie u nas nieznany choć miły jako anglista [Leszek] Elektorowicz $^{58}$, niż autentyści, którzy wcale nie wymarli, ale przecież piszą i stale jeszcze wydają. Czemu się o nich uparcie milczy? Jeśli wiesz, czemu i Ty milczysz? Przecież byłeś kiedyś z nami związany.

Nie bierz mi za złe tego wyrzutu, ale sądziłem, że rozumiesz lepiej, jak się sytuacja przedstawia. Przeglądałeś ostatnie antologie poezji polskiej, wydane z auspicji [Juliana] Przybosia i spółki w Jugosławii, Francji i NRF? Przecież to fałszywy i skarykaturowany obraz literatury! A co się robi w Anglii? ${ }^{59}$

Pietrkiewicz na sformułowany w liście zarzut oddalenia od autentyzmu nie odpowiedział od razu, ale uczynił to dopiero po dwóch latach, w reakcji na kolejny list Ożoga, w którym ten z jednej strony chwalił się otrzymaniem literackiej nagrody Ministra Kultury i Sztuki II stopnia, a z drugiej strony żalił, pisząc:

Z [Józefem] Frasikiem nie da się współżyć. Zerwałem z nim. Trochę za późno. Powinienem to zrobić dwadzieścia lat temu. O powodach ostatecznego zerwania wspomnia-

${ }^{53}$ Czasopismo nie było wydawane w okresie październik 1937-marzec 1938.

${ }^{54}$ List J. Pietrkiewicza do J. B. Ożoga, jesień 1937; podkr. autora.

${ }^{55}$ List J. Pietrkiewicza do J. B. Ożoga z 8 kwietnia 1948.

${ }^{56}$ List J. B. Ożoga do J. Pietrkiewicza z 30 grudnia 1957.

${ }^{57}$ J. B. Ożóg, Ucieczka, Lublin 1965.

${ }^{58}$ Leszek Elektorowicz, właśc. Lesław Witeszczak (1924-2019), poeta, prozaik, eseista, thumacz. Absolwent filologii angielskiej na Uniwersytecie Jagiellońskim. Debiutował w roku 1947, ale większość swoich prac twórczych ogłosił po odwilży $1956 \mathrm{r}$.

${ }^{59}$ List J. B. Ożoga do J. Pietrkiewicza z 14 września 1965. Podkr. autora. 
łem, zdaje się, [Bolesławowi] Taborskiemu ${ }^{60}$. To człowiek (Frasik) strasznie zawistny i nie przebierający w środkach ${ }^{61}$.

Pietrkiewicz nagrody pogratulował, a odnosząc się do konfliktu z Frasikiem, pytał:

Czy nie da się jakoś naprawić stosunków z Józefem Andrzejem? Tak mało nas autentystów - lata lecą - lepiej jak w rodzinie godzić się. Wyciągnij rękę wspaniałomyślnie, jeśli możesz. Wybacz, że tak radzę. [Stanisław] Czernik też napisał sporo (mimo woli?) niesprawiedliwości w mnie w studium w $O k\left[\right.$ olicy] Poetów ${ }^{62}$, nie mam żalu do niego. Trudno, pomylił fakty. Wierzę, że korektorka wieczna wszystko naprawia, łagodzi, przywraca do sensu ${ }^{63}$.

Odpowiedź Ożoga się nie zachowała, ale najwidoczniej rada Pietrkiewicza została przyjęta, ponieważ - o czym można się przekonać, czytając listy z początku lat 70 . Ożóg przerwaną relację odnowił. To zresztą rzecz znamienna dla postawy obu twórców — dbałość o relacje z pisarzami im bliskimi. I tak np. w liście z marca 1964 roku Ożóg informował Pietrkiewicza o wydaniu nowej książki ${ }^{64}$, dopytywał o wzmianki o sobie w prasie emigracyjnej, pisał: „Czytałem przed tygodniem bardzo dokładnie wypożyczoną w Bibliotece Jagiellońskiej Twoją powieść Po chłopsku ${ }^{65}$. Rzecz interesująca, pisana z [słowo nieczytelne]. Ciekawe są uwagi o autentyzmie" ${ }^{66}$, oraz — co istotne donosił o śmierci Stanisława Piętaka: „Chyba wiadomo Ci, że Staś Piętak nie żyje. Popełnił samobójstwo. Rzucił się z piątego piętra swojego mieszkania na bruk”. Pietrkiewicz odpowiadał: „Moje Po chłopsku to stare dzieje; gdybyś tylko mógł przeczytać coś angielsk[iego]. Bardzo się przejąłem śmiercią Piętaka - to jednak był autentysta"67. Ta ostatnia uwaga jest nieco zaskakująca w kontekście tego, co o twórczości Piętaka pisał Pietrkiewicz do Ożoga w liście z kwietnia 1948 roku.

Kolejny raz do autentyzmu Pietrkiewicz nawiązał w liście z 1 czerwca 1970 roku, jednocześnie odnosząc się do wcześniej wysłanego listu (nie zachował się w omawianych zbiorach korespondencji):

Drogi mój Janku,

Błagam Cię w imię autentyzmu naszych imion nie tytułuj mnie profesorem czy ja-

kimś innym stworem. Przecież jesteś jednym z najstarszych moich przyjaciół — inni wymierają $[\ldots]$

Mówiłem Ci w Krakowie, że coś zrobię dla autentyzmu po angielsku, co zostanie, a nie przejdzie z wiatrem dziennikarskim. Otóż dałem spory rozdział pt. Świadkowie (The Witnesses), w którym głównie Twoja poezja jest omawiana, z przekładami cytatów, a także tło okresu i zamierzenia teoretyczne. Książka sama jest o ogólnym problemie poezji

${ }^{60}$ Bolesław Taborski (1927-2010), poeta, teatrolog, krytyk, thumacz. Od 1943 r. w Warszawie, uczestnik powstania warszawskiego. Od 1946 r. w Londynie, w 1953 r. ukończył studia magisterskie w zakresie teatrologii na University of Bristol. Członek grupy poetyckiej „Kontynenty", oficjalny thumacz dzieł dramatycznych Karola Wojtyły (Jana Pawła II).

${ }^{61}$ List J. B. Ożoga do J. Pietrkiewicza z 29 września 1967.

${ }^{62}$ S. Czernik, Okolica poetów. Wspomnienia i materiaty, Poznań 1961.

${ }^{63}$ Karta pocztowa J. Pietrkiewicza do J. B. Ożoga z 28 października 1967.

${ }^{64}$ J. B. Ożóg, Dzikie jabłka, Warszawa 1964.

${ }^{65}$ J. Pietrkiewicz, Po chłopsku. Powieść, t. 1-2, Londyn 1941.

${ }^{66}$ List J. B. Ożoga do J. Pietrkiewicza z 30 marca 1964.

${ }^{67}$ Karta pocztowa J. Pietrkiewicza do J. B. Ożoga z 28 czerwca 1946. W opracowaniach poświęconych autentyzmowi Stanisław Piętak jest włączany do kręgu sympatyków, zwolenników autentyzmu; zob. np.: hasło Autentyzm [w:] Literatura polska XX wieku. Przewodnik encyklopedyczny, t. 1, red. A. Hutnikieiwcz, A. Lam, Warszawa 2000; M. Jakitowicz, Dopetnienie obrazu. Szkice o autentyzmie, Torun 1993. 
(granica słów i poznania, „druga strona ciszy”, bo taki tytuł) ${ }^{68}$. Znajdujesz się tam w dobrym towarzystwie, obok [Arthura] Rimbauda ${ }^{69}$, [Williama] Blake'a ${ }^{70}$, św. Jana od Krzy$\dot{z ̇ a}^{71}$, [Rainera] Rilkego ${ }^{72}$ etc. Ponieważ rzecz ma charakter porównawczy (nie o poezji polskiej wyłącznie), autentyzm, mam nadzieję, tą drogą wszedł do komparatystki jako znamienne zjawisko naszych czasów, a nie jako polsko-swojskie curiosum. Otóż ten właśnie rozdział był osobno drukowany w „London Magazine” przed ukazaniem się studium (była o nim spora recenzja z fotografią w „Times Lit[erary] Supp”[lement]).

W nowym wydaniu mojej antologii poezji polskiej po ang[ielsku] (która obejmuje tylko teksty poetów zmarłych) mówię o Tobie i o znaczeniu poezji wiejskiej w nowym wstępie. Pamiętaj, że tego rodzaju „ustawienie” problemu ważniejsze od sporadycznych przekładów ${ }^{73}$.

Ożóg odpowiedział serdecznie i wylewnie:

Ogromnie dziękuję za niezwykłe dowody przyjaźni i dobre a tak ważkie słowa o mojej robocie pisarskiej. Zdumiewa mnie i wzrusza Twoja pracowitość. O książce The Other Side of Silence dowiedziałem się na parę dni przed listem z „Oficyny Poetów”, której ostatni (17) numer dotarł szczęśliwie do Krakowa. Recenzja [Bolesława] Taborskiego ${ }^{74}$ dała mi już jakieś pojęcie o Twoich dociekaniach. Bądź pewny, zdaję sobie sprawę jak najmocniej, jaką przysługą dla autentyzmu i mojej poezji jest Twoja znakomita książka, tym więcej, że napisana w języku angielskim, a zatem dla najszerszych mas czytelniczych na świecie. Nikt z nas tego Ci nie zapomni. Tak żywi jak i umarli pamiętają. [...]

Każdą Twoją publikacją mocno się interesuję. Nie muszę chyba tłumaczyć, jak bardzo zależy mi na wszystkim, co odnosi się zwłaszcza do autentyzmu, dlatego czekam ze zniecierpliwieniem na numer „London Magazine” i nową antologię poezji polskiej. Jeśli nie wysłałeś jeszcze do Biblioteki Jagiellońskiej (gdzie zakatalogowano wszystkie, zdaje się Twoje obcojęzyczne publikacje) egzemplarza książki The Other Side of Silence, to - proszę Cię bardzo - wyślij dwa, w tym jeden dla mnie, z dedykacją, żeby trafił łatwiej do moich rąk. Rozmawiałem z dyrektorem Biblioteki dr. [Janem] Baumgardtem[! $]^{75}$ i zgodę na ewentualne przyjęcie egzemplarza dla mnie wyraził bez żadnych oporów. Za przysługę tak cenną będę Ci się rewanżował skromnymi możliwościami do końca moich dni ${ }^{76}$.

Jak zatem widać, każda publikacja czy choćby wzmianka o autentystach budziła spore emocje. Podkreślając wagę poszczególnych druków, dystrybuując wiedzę o nich

${ }^{68}$ Zob.: J. Peterekiewicz, The other side of silence. The poet at the limits of language, London 1970. Wyd. polskie: Druga strona milczenia. Poeta u krańców mowy, przeł. J. Jackowicz, Warszawa 2002.

${ }^{69}$ Arthur Rimbaud (1854-1891), francuski poeta zaliczany do tzw. poetów wyklętych. Jeden z głównych przedstawicieli parnasizmu i symbolizmu.

${ }^{70}$ William Blake (1757-1827), angielski poeta, malarz, mistyk, zaliczany do tzw. poetów wyklętych. Prekursor romantyzmu, akcentujący nadrzędną rolę świata duchowego.

${ }_{71}$ Św. Jan od Krzyża (1542-1591), hiszpański teolog, poeta, mistyk, zakonnik, doktor Kościoła. Autor dzieł z zakresu ascetyki i poematów mistycznych.

72 Rainer Maria Rilke (1875-1926), austriacki poeta, prozaik, eseista. Jeden z głównych przedstawicieli symbolizmu, prekursor egzystencjalizmu.

${ }^{73}$ List J. Pietrkiewicza do J. B. Ożoga z 1 czerwca 1970; podkr. autora. Dodatkowo Pietrkiewicz informował Ożoga o swoim liście do redakcji „Kultury”, w którym także poruszał problem autentyzmu; zob.: J. Pietrkiewicz, List o S[tanistawie] Czerniku, Kultura 1970 nr 3 (270), s. 134-135.

${ }_{75}^{74}$ B. Taborski, Poeta u krańców języka, Oficyna Poetów 1970 nr 17, s. 18-20.

75 Jan Baumgart (1904-1989), bibliotekarz, profesor Uniwersytetu Jagiellońskiego, dyrektor Biblioteki Jagiellońskiej, przewodniczący Stowarzyszenia Bibliotekarzy Polskich w latach 1966-1969.

${ }^{76}$ List J. B. Ożoga do J. Pietrkiewicza z 14 czerwca 1970. 
(„O Twoich pracach powiadomiłem przede wszystkim [Józefa] Frasika. I swoich znajomych wśród pisarzy"77), obaj autorzy zabiegali o jak najpełniejszą prezentację nurtu i dokonań poszczególnych twórców. Potknięcia i odstępstwa od tej reguły spotykały się z ich żywą reakcją. W przywołanym liście Ożóg pytał:

Czy jesteś w mocniejszych kontaktach z „Oficyną”? W artykule moim Autentyzm czy co innego ${ }^{78}$ zecer puścił od siebie cholerny błąd stylistyczny. W pierwszej szpalcie, jest „występował też przeciw niektórych postulatów Awangardy”. Jak sądzisz, czy nie zrobił tego [Czesław] Bednarczyk ${ }^{79}$ naumyślnie? ${ }^{80}$

Publikacje, na które czekał Ożóg, dość szybko dotarły do Krakowa, o czym donosił w kolejnym liście, dodatkowo komplementując ich autora:

Praca Twoja jest znakomita. Stylem dobrego plastyka oddałeś zdumiewająco trafnie i wnikliwie dramat polskiej wsi i autentystów. Jestem naprawdę pełen podziwu dla Twojego serca, dla Twoich wzruszeń i niezwykłej dociekliwości. [...]

Mimo wszystko jesteś w znakomitej formie. Jako pisarz i naukowiec. Oczywiście pozycja Twoja w literaturze angielskiej zaważy przede wszystkim w chwili kiedy nasi ludzie od spraw kultury będą sobie musieli przypomnieć, że należysz także i to jak najbardziej to literatury polskiej ${ }^{81}$.

Dodawał: „Był przed paroma dniami u mnie [Józef] Frasik. Przeczytałem mu Twój esej. Jest usatysfakcjonowany", i deklarował, że prace londyńskiego przyjaciela przybliży gronu osób zainteresowanych (wymieniał m.in. wdowę po Stanisławie Piętaku Aleksandrę $^{82}$, [Włodzimierza] Maciąga ${ }^{83}$, [Kazimierza] Wykę ${ }^{84}$, Zbigniewa Bieńkowskiego $^{85}$ ). Sugerował też, że jest to dobry moment, aby „zainteresować właśnie teraz prozą Twoją któreś z naszych wydawnictw”, do czego gorąco namawiał autora Prowincji, zastrzegając jednocześnie, że:

Niestety przy naszej narodowej nieruchawości i uprzedzeniach trzeba szukać dziwnymi drogami nieraz jakichś kontaktów. Żydzi niestety dużo popsuli. Nie będę przypominał, to są smutne sprawy, opinia jest w większości strasznym narzędziem, odczułem to sam na własnej skórze, Jurku.

Pietrkiewicz na tę ostatnią sugestię nie zareagował, starał się natomiast usprawiedliwić Bednarczyka: „Nie przejmuj się, proszę, błędem stylistycznym w »Oficynie « pismo to grzeszy czasem słabą korektą. Na pewno [Czesław] Bednarczyk nie chciał

\footnotetext{
${ }^{77}$ Tamże.

${ }^{78}$ J. B. Ożóg, Autentyzm, czy co innego?, Oficyna Poetów 1970 nr 17, s. 4.
}

${ }^{79}$ Czesław Bednarczyk (1912-1994), poeta, prozaik, wydawca. Uczestnik kampanii wrześniowej 1939, następnie oficer 2. Korpusu. Od 1946 r. w Wielkiej Brytanii, gdzie z żoną, Krystyną, prowadził w Londynie wydawnictwo Oficyna Poetów i Malarzy. W latach 1967-1980 był redaktorem naczelnym i wydawcą kwartalnika literacko-artystycznego „Oficyna Poetów”.

${ }^{80}$ List J. B. Ożoga do J. Pietrkiewicza z 14 czerwca 1970.

${ }^{81}$ List J. B. Ożoga do J. Pietrkiewicza z 17 lipca 1970.

${ }^{82}$ Aleksandra Piętak, z domu Kosińska. Żona Stanisława Piętaka od 1946 r.

${ }^{83}$ Włodzimierz Maciąg (1925-2012), historyk literatury, krytyk literacki, powieściopisarz, profesor Uniwersytetu Jagiellońskiego.

${ }^{84}$ Kazimierz Wyka (1910-1975), historyk literatury, krytyk literacki, eseista, profesor Uniwersytetu Jagiellońskiego, poseł na Sejm PRL I kadencji, współtwórca i dyrektor Instytutu Badań Literackich.

${ }^{85}$ Zbigniew Bieńkowski (1913-1994), poeta, krytyk literacki, tłumacz, redaktor „Twórczości”, członek polskiego PEN Clubu. 
Cię dotknąc ${ }^{86}$ - on szanuje i autentyzm, i Ciebie" ${ }^{97}$. Na pocieszenie dodawał (na marginesie informacji, że wysłane przez niego publikacje dotarly do Krakowa):

Cieszę się, że masz dowód mojego umiłowania Twojej poezji. Zauważ że Twoje nazwisko jest wytłuszczone w indeksie jako jedno $\mathrm{z}$ ważniejszych w całym ogrodzie. Magazyn zawiera wyciąg, ale to do Twoich dokumentów autentyzmu.

Ożóg, pozostając pod wrażeniem lektury, zaczął - jak wynika z listu 17 lipca 1970 r. - zabiegać o przełożenie szkicu Świadkowie na język polski. Pietrkiewicz przyjął tę wiadomość z umiarkowanym zadowoleniem, zastrzegając, że nie godzi się na żadne skróty i uzależnia druk od uzyskania przez którekolwiek z polskich czasopism czy wydawnictw zgody Oxford University Press. Dodawał: „Ta książka jest tu czytana — doszła do bibliotek, także w Ameryce. Jestem uszczęśliwiony i dumny, że mogłem o Twoim imponującym dorobku pisać i traktować Cię na równi z wielkimi poetami innych krajów" ${ }^{\prime 88}$.

Szkic został przełożony przed dwoje niezależnych tłumaczy i zgłoszony do druku w ,Życiu Literackim”. Po czym, jak referował Ożóg:

[...] tam go kolegialnie odrzucono. Tekst leży tam jeszcze, dowiedziałem się, że czeka-

ją na decyzję naszego redaktora, ale naczelny [Władysław] Machejek ${ }^{89}$, wyjechał na

Kubę, już miesiąc temu i jeszcze nie wrócił. Nadziei, mimo wszystko, na druk jest nie-

wiele, a szkoda, bo praca Twoja jest bardzo wnikliwie i pięknie napisana ${ }^{90}$.

Poruszony tym Ożóg deklarował, że gdyby rzeczywiście tekst nie ukazał się w „Życiu Literackim”, to postara się nim zainteresować redakcję „Poezji” („Tam może będą większe szanse”). Sam Pietrkiewicz sprawę zbagatelizował: „Domyślam się, że to tłumaczenie rozdz[iału] o autentyzmie nie mogło się ukazać, co w pełni rozumiem. To nieważne zresztą",91.

Rok 1971 upłynął Ożogowi na podkreślaniu roli i znaczenia dokonań autentystów, w tym Pietrkiewicza. Donosił w kolejnych listach:

Pod koniec kwietnia ukaże się nowa moja książka. Będą to wspomnienia literackie ${ }^{92}$. Jest tam passus i o Tobie, niestety mocno obcięty. Prześlę egzemplarz ${ }^{93}$.

W dzień po Twoim wyjeździe zjawił się w kioskach nowy numer „Współczesności”. Po zakupieniu go znalazłem moją wypowiedź z festiwalu poetyckiego, jaki się odbył w Łodzi. Wycinek z artykułem pozwalam sobie przesłać na Twe ręce, w nadziei, że Cię interesują nadal sprawy autentyzmu ${ }^{94}$.

Dwa listopadowe tygodnie spędziłem w Zagrzebiu, gdzie odbywało się przez kilka dni międzynarodowe sympozjum literackie. Było dwadzieścia delegacji z Zachodu [...] Wygłosiłem referat „O autentyczności poezji”.

${ }^{86}$ Zob.: Do poprawienia (dot. art. J. B. Ożoga: „Autentyzm, czy co innego”), w rubryce: „Kronika i różne”, Oficyna Poetów 1970 nr 18, s. 48.

${ }^{87}$ List J. Pietrkiewicza do J. B. Ożoga z 21 lipca 1970.

${ }^{88}$ List J. Pietrkiewicza do J. B. Ożoga z 5 października 1970.

${ }^{89}$ Władysław Machejek (1920-1991), pisarz, publicysta, działacz komunistyczny. W latach 1952-1989 był redaktorem naczelnym „Życia Literackiego”. Członek PZPR, z ramienia której był posłem na Sejm czterech kadencji (1957-1972).

${ }^{90}$ List J. B. Ożoga do J. Pietrkiewicza z 17 grudnia 1970.

${ }^{91}$ Karta pocztowa J. Pietrkiewicza do J. B. Ożoga z grudnia 1970.

92 J. B. Ożóg, Na mojej drodze. Wspomnienia, Kraków 1971.

${ }^{93}$ Karta pocztowa J. B. Ożoga do J. Pietrkiewicza z 8 kwietnia 1971.

${ }^{94}$ List J. B. Ożoga do J. Pietrkiewicza z 29 sierpnia 1971. 
Wydawnictwo Literackie (w Krakowie) przyjęło do druku zbiór moich artykułów i esejów o autentyzmie-introwertyzmie, ale trzeba czekać dwa lata ${ }^{95}$. Jestem bardzo zadowolony, eseistyka jest deficytowa i bardzo, bardzo trudno ją upchnąć. Mam kłopot zwalony z głowy, bo rzecz wstawiona jest już do planu wydawniczego - oczywiście po przejściu przez recenzentów. Mogę Cię zapewnić, że tym razem będzie o Tobie dużo ${ }^{96}$.

Zapowiedziany tom esejów ukazał się nie po dwóch, lecz po czterech latach. Pietrkiewicz po otrzymaniu egzemplarza pisał:

Dzięki za tom o autentyzmie. Dobrze żeś to wydał. Zrobi swoje. Wiesz, że moje ang[ielskie] studium, w którym jest rozdział o autent[yzmie] (głównie o Tobie) znajduje się w bibliotekach po obu stronach oceanu i jest cytowane w innych pracach krytycznych ${ }^{97}$.

Dodawał także, że przygotowuje drugie, krajowe wydanie Prowincji (do czego ostatecznie nie doszło), choć - jak zastrzegał: „Ja nie dbam o moją polską twórczość, bo dziś inna mnie absorbuje, ale widać sądzone mi być pośmiertnym u swoich”.

Następne, coraz rzadziej słane listy Ożoga do Pietrkiewicza, utrzymane były w podobnym, informacyjnym tonie. Krakowski poeta donosił w nich o kolejnych publikacjach przygotowywanych do druku i o związanych z autentyzmem inicjatywach:

W dniach 3 i 4 czerwca b.r. ${ }^{98}$ odbyła się w Ostrzeszowie sesja naukowa „Dziedzictwo autentyzmu”. Referaty wygłosili młodzi krytycy i pracownicy ${ }^{99}$ naukowi z Uniwersytetu Łódzkiego. Najciekawsza była praca Jerzego Tyneckiego „Autentyzm z punktu widzenia historii literatury". Z okazji owej imprezy wydano małą Antologie poezji autentystów w formie numeru okolicznościowego „Okolicy Poetów”, ze wstępem Andrzeja Biskupskiego ${ }^{100}$. Wiersze wzięło z „Okolicy”. Z Twoich znalazły się tam: Ziemia Dobrzyńska, Baśń, Powrót do wsi rodzinnej (fragment z poematu Jesteś Polakiem) i *** (Rozkopać słowa). Otrzymałem tylko jeden egzemplarz, nie udało mi się wziąć drugiego nawet dla [Józefa] Frasika, który z powodu choroby nie mógł pojechać. Jeśli Ci zależy na tej publikacji zwróć się po nią pod adres: Dyrekcja / Biblioteki Publicznej Miasta i Gminy im St. Czernika / ul. Barek 17 / Ostrzeszów /. Nakład mały (800 egz.), ale może mają tam jeszcze jakieś zasoby. Podaj krótko Swoje racje i adres. [...]

W wydawnictwie Literackim wyjdzie jeszcze w tym roku książka moich artykułów Wierność sobie i ziemi $^{101}$, w której zająłem się przede wszystkim warsztatem twórczości i stylem poetów - autentystów. Są, oczywiście, także cytaty z Twoich wierszy. W Wydawnictwie Łódzkim przyrzekają mi druk następnej, trzeciej książki o autentyzmie ${ }^{102}$.

Alicja Moskalowa ${ }^{103}$ z Londynu ogłosiła w Ludowej Spółdzielni Wykładowczej pracę doktorską o autentystach ${ }^{104}$. Za niedługo ukaże się książka ta w sprzedaży i dotrze jakiś

${ }^{95}$ J. B. Ożóg, Mój autentyzm, Kraków 1975.

${ }^{96}$ List J. B. Ożoga do J. Pietrkiewicza z 23 grudnia 1971.

${ }^{97}$ Karta pocztowa J. Pietrkiewicza do J. B. Ożoga z 30 czerwca 1975.

${ }^{98}$ List J. B. Ożoga do J. Pietrkiewicza z 25 lipca 1978.

${ }^{99}$ Skreślone słowo „historycy”.

${ }^{100}$ Okolica poetów. Antologia poezji autentystów, oprac. A. Biskupski, Łódź 1978.

${ }^{101}$ J. B. Ożóg, Wierność sobie i ziemi. Szkice o autentyzmie, Kraków 1980.

102 Tenże, Z manowców na prosta drogę, Łódź 1983.

${ }^{103}$ Alicja Moskalowa (1928-2020), historyk literatury, thumaczka. Studiowała filologię polską i rosyjską na Uniwersytecie Warszawskim. W 1957 r. wyjechała do Londynu, gdzie w 1972 r. uzyskała magisterium ze slawistyki na Polskim Uniwersytecie na Obczyźnie, a następnie w 1978 r. doktorat z zakresu filologii polskiej. Wykładowczyni PUNO.

${ }^{104}$ A. Moskalowa, Autentyzm w polskiej poezji międzywojennej, Warszawa 1979. 
egzemplarz z pewnością do Ciebie. Oprócz tego wyjdzie również w tym samym wydawnictwie tom Twoich poezji wybranych w „Bibliotece Poetów XX w.” ${ }^{\text {.105 }}$.

Na ostatni z przywołanych listów ${ }^{106}$ Pietrkiewicz nie odpowiedział, co Ożóg wypominał mu w kolejnym ${ }^{107}$, imputując, że jego przyjaciel przeraził się nakreśloną w nim wizją przyjazdu krakowskiego poety wraz z synem do Londynu i zawarta w liście prośbą o odebranie $\mathrm{z}$ lotniska i znalezienie niedrogiego hotelu. Jednak najwięcej miejsca w tej epistole Ożoga znalazły uwagi krytyczne dotyczące doktoratu Moskalowej. Pisał on m.in.:

$\mathrm{P}$ [ani Alicja] Moskalowa odwiedziła mnie przed dwoma laty, udzieliłem jej pewnych wiadomości ustnych i także listownych, dotyczących twórczości autentystów. Przestrzegałem ją przed zaliczaniem do tej grupy [Tadeusza] Demczyka, [Stefana] Szajdaka, a przede wszystkim [Bolesława] Kobrzyńskiego ${ }^{108}$. Nie posłuchała mnie. Książkę Autentyści w polskiej poezji międzywojennej, która ukazała się w Ludowej Spółdzielni Wydawniczej tak starannie, że budzi to podziw, kupiłem przed paroma dniami i przejrzałem ją, ale z pomieszanymi wrażeniami. Zdumiewa mnie niezwykle wielki kawał tego druku o Kobrzyńskim. Że jakiś tam nieodpowiedzialny krzykacz, któregośmy dobrze znali na uniwersytecie krakowskim, ale z najgorszej strony, w tomiku słabych wierszy wojennych zaliczył Kobrzyńskiego na ślepo do autentystów, ma być świadectwem prawdy? Nabrał się [Stanisław] Czernik, ciągle popełniający horrendalne pomyłki, ale ja zgodzić się na to nie mogę. W swoich wypowiedziach ,terroretycznych” [!] ujawnia się Kobrzyński jako maniak, śmieszny nuworysz. Siadło temu przeciętniakowi w sztuce poezjowania coś ${ }^{109}$ i bidna pani M[oskalowa] uwierzyła, że ma przed sobą Arystotelesa.

Dalszym nieporozumieniem jest twierdzenie p. Moskalowej, że autentyści to tylko jesieninowcy i nic więcej. Wbrew wszelkiej oczywistości, ten sąd rozciąga się na robotę wszystkich autentystów.

Rzecz miała się ograniczyć do okresu międzywojennego, a tymczasem, kreśląc portrety Londyńczyków, wykracza autorka daleko za rok 1945. To nie jest w porządku. Nie jestem megalomanem, ale każdy by $\mathrm{Ci}$ z piszących tu, w kraju, także z najzacieklejszych wrogów, powiedział, że gdyby nie mój i tylko mój fantastyczny upór w przypominaniu doktryny (za co okładano mnie knutami) i poszerzaniu jej, upór popierany odpowiedzialną praktyką poetycką termin ,autentyzm” zostałby w języku zupełnie zapomniany i w konsekwencji nie byłoby pracy p. Moskalowej. Możesz się z tym zgodzić lub nie, fakt zostanie faktem.

Nie posądzaj mnie o małostkowość, ale dziwię się, że p. Moskalowa ograniczyła mój życiorys tylko do ucieczki z seminarium duchownego. Była u mnie i gdyby kierowała nią lepsza wolą, przecież zapytałaby się o to, jakie przynajmniej odbyłem studia. Nie należy do tajemnic, że ukończyłem polonistykę na nie najgorszej uczelni, bo najstarszym u nas Uniwersytecie Jagiellońskim, ze stopniem magistra. Wykładowcom w liceach po wojnie byłem dobrym, skoro w r. 1949 proponowano mi niedwuznacznie objęcie zajęć na jednym z uniwersytetów niemieckich. Gdybym chorował na tytuł doktora, uzyskałbym dyplom bez trudności, jak mi się zdaje, już dawno, np. w r. 1956 (po wydaniu książki Macie-

105 J. Pietrkiewicz, Kula magiczna, Warszawa 1980.

${ }^{106}$ List J. B. Ożoga do J. Pietrkiewicza z 11 grudnia 1979.

${ }^{107}$ List J. B. Ożoga do J. Pietrkiewicza z 29 stycznia 1980.

${ }^{108}$ Tadeusz Demczyk, Stefan Szajdak i Bolesław Kobrzyński byli zaliczani do grona autentystów przez Stanisława Czernika i część historyków literatury. Zob.: S. Czernik, Okolica poetów; Z. Andres, Świadek codzienności - Jerzy Pietrkiewicz, Zeszyty Naukowe Uniwersytetu Rzeszowskiego. Seria Filologiczna. Historia Literatury 2011 z. 70, s. 248-259; M. Jakitowicz, Dopetnienie obrazu. Szkice o autentyzmie, Toruń 1993.

${ }^{109}$ Skreślone słowa „na głowie”. 
ja Szarka ${ }^{110}$ ). To nie znaczy, żebym się wyrzekał stopnia magisterskiego i godził żeby mi go ktoś odbierał. Dyplomu magisterskiego Frasikowi p. Moskalowa przypomnieć potrafiła [!], choć z mylną datą (pracę dyplomową doniósł dopiero około r. 1960 (dokładnie nie pamiętam) ${ }^{111}$. Jeszcze jedno. W czasie wojny byłem w ZWZ, a potem w AK. Ukończyłem w podziemnych ciężkich warunkach podchorążówkę i do oddziałów partyzanckich poszedłem ochotniczo. Konspiracyjne władze wojskowe ode mnie tego nie żądały, miałem zlecone funkcje prasowe, a nie bojowe. W partyzantce otrzymałem awans na oficera, brałem udział w kilku potyczkach i w bitwie pod Porębami Kupińskimi w Puszczy Sandomierskiej, w której wybito ponad 60 Niemców. Byłem kontuzjowany, posiadam legitymację inwalidy wojennego. Całą tę historię była łaskawa p. Moskalowa skwitować bardzo prosto: Ożóg był sobie partyzantem.

Dużo nasuwa się uwag, książka roi się od wielu innych błędów. [Stanisława] Młodożeńca $^{112}$ zalicza p. Moskalowa do awangardzistów, a przecież wszyscy wiemy, że należy do formacji literackiej znacznie starszej, był futurystą. Oenerowskiego, nikomu nie znanego, pachołka T[adeusza] Dworaka ${ }^{113}$ robi p. Moskalowa krytykiem i wsadza w książkę — bez komentarzy co do osoby — cytaty z jego obelżywej napaści na moją osobę rzekomo w imię rzeczywistości dla... obrony autentyzmu. Przypomnij sobie, Kochany, jakie sądy wygłaszał na temat Twojej Prowincji np. Czachowski ${ }^{114}$. Czemu p. Moskalowa o tym nie wspomina?

Nie sposób w krótkim liście wszystko o książce powiedzieć. Ma ona, oczywiście i dobre strony. Tym bardziej chciałbym przyjechać do Londynu, aby te sprawy omówić z Tobą i p. Moskalową. Myślę, że zaciągnęła u autentystów przede wszystkim tych, którzy zostali w kraju, poważne długi moralne i powinna się z nich uiścić solidną, większą książką o ich dorobku powojennym.

Kończąc, ponownie przypominał, że trwa proces wydawniczy zbiorów szkiców Wierność sobie i ziemi oraz $Z$ manowców na prosta droge, po czym dodawał:

Do Państwowego Instytutu Wydawniczego oddałem wreszcie obszerną antologię poezji „Autentyści i sąsiedzi"115 — jesteś w niej dobrze reprezentowany.

Jak widzisz, wypruwam wszystkie żyły i tętnice z siebie, żeby gromada „okoliczan” i autentystów powojennych ukazała się światu w barwach jasnych, pełnych.

Także w kolejnych listach — z 31 lipca $^{116}$ i 2 grudnia $^{117}$ — Ożóg koncentrował się na swoich publikacjach, a także wszystkich tych, w których pojawiały się omówienia lub twórczość autentystów. W liście grudniowym pisał:

Walka o autentyzm nie jest łatwa. Powody są ci przecież znane. Programy autentyzmu były i są, celowo najczęściej, interpretowane mylnie. Postawangardowi snobi opanowali nie tylko wszystkie masowe środki przekazu, ale i katedry uczelniane, i z nimi najtrudniej się dogadać. [...]

\footnotetext{
${ }^{110}$ M. Szarek, Wiersze i proza, oprac. J. B. Ożóg, Warszawa 1956.

${ }^{111}$ Józef Frasik studia magisterskie ukończył w 1937 roku.

${ }^{112}$ Stanisław Młodożeniec (1895-1959), poeta, prozaik. W 1918 r. rozpoczął studia polonistyczne na Uniwersytecie Jagiellońskim, gdzie wraz z Brunonem Jasieńskim zbliżył się do Tytusa Czyżewskiego i środowiska formistów. Założył razem z nimi klub Katarynka i wraz z Aleksandrem Watem i Anatolem Sternem utworzyli grupę futurystów.

${ }^{113}$ Tadeusz Dworak, krytyk literacki, przed drugą wojną światową współpracownik „Prosto

${ }^{114}$ Kazimierz Czachowski (1890-1948), krytyk literacki, historyk literatury. Drukował m.in. w „Wiadomościach Literackich”, „Czasie”, „Gazecie Literackiej”, „Gazecie Polskiej”.

${ }^{115}$ Okoliczanie. Antologia poezji polskiego autentyzmu, oprac. J. B. Ożóg, Warszawa 1984.

${ }^{116}$ List J. B. Ożoga do J. Pietrkiewicza z 31 lipca 1980.

${ }^{117}$ List J. B. Ożoga do J. Pietrkiewicza z 2 grudnia 1980.
} z Mostu". 
Wracam jeszcze do książki mojej Wierność sobie i ziemi. Tenor jej zbiega się z nastrojami ogólnymi w kraju i w świecie. Mówi się o autentycznym człowieku, o autentycznym życiu. Naprawdę, książka nie powinna przejść bez echa.

Pietrkiewicz utwierdzał przyjaciela w jego sądach — pisał w listopadzie 1980 roku: „Istotnie zrobiłeś dużo dla autentyzmu, trwając przy nim pilnie. To Ci wszyscy teraz przyznają"118. Korzystając o okazji, krytykował także książkę Kazimierza Koźniewskiego Historia co tydzieńn ${ }^{119}$, o której Ożóg doniósł mu ze słowami: „Wspomina Cię mydłek kilkanaście razy, nie szczędząc ciosów" ${ }^{\text {"120 }}$. Pietrkiewicz komentował zawarte w tej książce rewelacje następująco:

Co do tego Koźniew[skiego], to typowa niesprawiedliwość — tak rozprawiano się za stalinowskich czasów ze zmarłymi i nieobecnymi. Ten typ ignoruje celowo wszystko co zrobiłem dla kultury polskiej przez ostatnie czterdzieści lat. Tylko umie pluć bo tak się nauczył, a innym kadzi. Czytać go nie chcę, bo do gnoju nie wkłada się nosa ${ }^{121}$.

Jak widać, prywatny charakter korespondencji i wzajemne zaufanie skłaniały obu autorów do wydawania sądów ostrych i wyrazistych. Takich, jak choćby ten Ożoga o Józefie Łobodowskim ${ }^{122}$ :

Czy kontaktujesz się z Łobodowskim? Rzucił się niespodzianie śmierdziuch w styczniowym numerze „Wiadomości” 123 na Czernika i „Okolicę Poetów” — przypomniał sobie! Nie wiesz przypadkiem, kto go podszczuł? Zapobiegliwy chytrus wysyła skrzętnie wszystkie swoje pakowne książczydła do Biblioteki Narodowej i Biblioteki Jagiellońskiej, ale czytelników nie znajduje - to poezja zastraszająco prostacka, podobnie jak publicystyka $^{124}$

Drapieżni w osądach wrogów, ciepłymi myślami otaczali przyjaciół. W odpowiedzi na informację o śmierci Frasika ${ }^{125}$ Pietrkiewicz pisał:

[...] zasmuciła mnie wiadomość o śmierci Frasika. Zostało nas tylko dwu [!], ale autentyzm zostanie w literaturze po nas, nie mam co do tego wątpliwości. Jeśli żyje żona Frasika, proszę przekaż jej załączony list. Żal mi jej ${ }^{126}$.

W listach z drugiej połowy lat 80. coraz częściej miejsce uwag o kolejnych publikacjach zajmują informacje o słabnącym zdrowiu obu pisarzy. I choć już wcześniej dzielili się tego typu troskami, to jednak przekraczający siedemdziesiąty rok życia autorzy koncentrują się na tych bolączkach w coraz większym stopniu. Ożóg pisze

\footnotetext{
${ }^{118}$ Karta pocztowa J. Pietrkiewicza do J. B. Ożoga z 15 listopada 1980.

${ }^{119}$ K. Koźniewski, Historia co tydzień. Szkice o tygodnikach społeczno-kulturalnych, Warszawa 1976.

${ }^{120}$ List J. B. Ożoga do J. Pietrkiewicza z 31 lipca 1980.

${ }^{121}$ Por. także karta pocztowa J. Pietrkiewicza do J. B. Ożoga z 19 stycznia 1981, gdzie pisał m.in.: „Mało to mnie już wzrusza, że pomija się mnie tak skrzętnie (czym chata bogata) — sprawiedliwość nie rychliwa".

122 Józef Łobodowski (1909-1988), poeta, prozaik, tłumacz. W 1931 r. podjął studia prawnicze na KUL-u, skąd został relegowany rok później za lewicową działalność polityczną. Związany poetycko z Józefem Czechowiczem i awangardą lubelską. Uczestnik kampanii wrześniowej 1939 r., od 1941 r. w Hiszpanii, gdzie w latach 1949-1975 był członkiem współpracownikiem sekcji polskiej radia w Madrycie.

${ }^{123}$ J. Łobodowski, Kilka słów o autentyzmie, Wiadomości $1981 \mathrm{nr} 1$ (1814), s. 20.

${ }^{124}$ List J. B. Ożoga do J. Pietrkiewicza z 15 maja 1981.

${ }^{125}$ Karta pocztowa J. B. Ożoga do J. Pietrkiewicza z 31 grudnia 1983.

${ }^{126}$ Karta pocztowa J. Pietrkiewicza do J. B. Ożoga, brak daty; po 31 grudnia 1983.
} 
m.in. o cukrzycy, słabnącym sercu i trzustce ${ }^{127}$, a także o chorobach swojej żony ${ }^{128}$, Pietrkiewicz pisze bardziej ogólnie albo o pobytach w szpitalu, albo o niedobrym samopoczuciu („Czuję się mizernie z wiosną, ${ }^{29}$ ). Nadal informują się o swoich pracach, dzielą się uwagami o wzmiankowaniu autentyzmu w tej czy innej publikacji.

Można powiedzieć, że nic nie zapowiadało nadciągającej burzy. Ożóg na jednej z kart pocztowych wysłanych do Londynu notował: „Listy Twoje zachowuję, wszystkie, od czasów przedwojennych" ${ }^{\text {"130 }}$. Pietrkiewicz na nią zapewne nie odpisał. Natomiast w kilka miesięcy później wysłał do Ożoga list, w którym prosił:

Napisz coś od siebie, nie tylko pośpieszny, malutki list. Zostało nas dwu [!] — obowiązuje nas lojalność wobec tego co łączy od wewnątrz. Wyślij pocztą poleconą listy sprzed wojny i może pierwsze dwa po wojnie (chyba z 1946 r.) — chodzi o materiał $\mathrm{z}$ tego okresu transformacji. Jak wiesz, wedle prawa, Copywright należy do wysyłającego listy, a po części do odbiorcy. Najlepiej posłać przez kogoś solidnego co jedzie do Londynu, żeby nie zaginęły.

Przyjmij skromny tom z serii, w której jesteś — przypomnij sobie wiersz pt. Zwykła opowieść — wymowa nazw — z $1936 \mathrm{r}$.

No, i trzymaj się, chłopie, nie poddawaj się chorobom — w górę łeb! ${ }^{131}$

Ożóg zareagował ${ }^{132}$ zaskakująco ostro. Rozpoczął od krytycznej oceny dokonań literackich Pietrkiewicza:

Tomik z wyborem wierszy ${ }^{133}$ otrzymałem. Wstęp Twój i wiersze niezupełnie udane. Nie robi też dobrego wrażenia panegiryczne posłowie p. Moskalowej.

Przejrzałem z Biblioteki Jagiellońskiej dwie inne Twoje książki. Zgrabna przetłumaczona przez p. Moskalową powieść ${ }^{134}$ nie podoba mi się. Jeśli się podoba innym w Anglii, to ich sprawa. Nie gustuję w tego rodzaju eksperymentach treściowych. Czy to nowatorstwo? Nie wiem. Wolę inne przykłady nowatorstwa, nie sądź, że się w Krakowie nie czyta nowości literackich. W książce esejów ubawiła mnie ogromna, autentycznie profesorska notatka o polskim autentyzmie, zamieszczona w odsyłaczu ${ }^{135}$. No cóż, zrobiłeś (he, he) dużo — zamieściłeś moje nazwisko, dziękuję za łaskawość.

Zaszyłem się od najwcześniejszych lat skromnego pisania w ciemne ściany mieszkania i nie szukam reklamy u nikogo, z nikim nie piję, nie wolno mi zresztą pić, mam inwalidztwo wojenne z partyzantki (akowskiej oczywiście), jestem poważnie chory. Książki moje idą w zapomnienie. [...]

Rozgoryczony pisał, podkreślając po raz kolejny własne dokonania:

Dla autentyzmu zrobiłem, jak mi się zdaje, dużo. Niektórzy sądzą, że autentyzm żyje w pamięci współczesnych obserwatorów tylko dzięki mnie. Mniejsza o to, nie umniejszam roli [Stanisława] Czernika w budowie teorii. Wiele pisałem o autentystach w pięciu wydanych o zjawisku książkach ${ }^{136}$. Ale ze strony autentystów nigdy, nigdy nie wyczyta-

${ }^{127}$ Zob. np.: list J. B. Ożoga do J. Pietrkiewicza z 17 sierpnia 1986.

${ }^{128}$ List J. B. Ożoga do J. Pietrkiewicza, brak daty; po 5 kwietnia 1985.

${ }^{129}$ Karta pocztowa J. Pietrkiewicza do J. B. Ożoga z 5 kwietnia 1985.

${ }^{130}$ Karta pocztowa J. B. Ożoga do J. Pietrkiewicza z 27 października 1986.

${ }^{131}$ List J. Pietrkiewicza do J. B. Ożoga z 6 czerwca 1987.

${ }^{132}$ List J. B. Ożoga do J. Pietrkiewicza z 5 sierpnia 1987.

${ }_{133}^{13}$ J. Pietrkiewicz, Poezje wybrane, posł. A. Moskalowa, Warszawa 1986.

${ }^{134}$ Tenże, Gdy opadaja tuski ciała, przeł. A. Moskalowa, Warszawa 1986.

${ }^{135}$ Tenże, Literatura polska $w$ perspektywie europejskiej. Studia i rozprawy, przeł.. A. Olszewska-Marcinkiewicz, I. Sieradzki, oprac. J. Starnawski, Warszawa 1986, s. 8.

${ }^{136}$ Obok już wspomnianych zbiorów: Mój autentyzm (1975), Wierność sobie i ziemi. Szkice o autentyzmie (1980), Z manowców na prosta drogę (1983), mowa zapewne o: J. B. Ożóg, Na 
łem o sobie jakiegoś znaczącego słowa uznania czy wdzięczności. Mimo to wiersze moje i częściowo opowiadania przekładają obcy mi ludzie na szanujące się języki europejskie i zamieszczają je w czołowych światowych czasopismach literackich. Należy do nich także chyba „Inostrannaja Literatura” — nie? I tam doczekałem się swojego miejsca.

A swojemu przyjacielowi czynił takie wyrzuty:

Od Ciebie miałem właściwie tylko jeden przed wojną otrzymany list, nieco dłuższy, ale bez znaczenia. Cała reszta korespondencji Twojej to nic innego tylko stos suchych, grzecznościowych pocztówek. Nie groź mi zatem paragrafami praw copywrightu — ta kupa papieru nadaje się tylko do spalenia, wcześniej czy później całe szuflady z korespondencją pójdą do pieca.

Kończąc list, domniemywał:

Po gorzkich słowach, jakie tu rzuciłem, nie spodziewam się, że zatrzymasz książeczkę, którą załączam ${ }^{137}$ (dwa inne szkice o literaturze w druku). Ale dobrze by było, żebyś ją mimo wszystko uważnie przeczytał.

Pietrkiewicz odpowiedział polubownie, nie podjąwszy rękawicy ${ }^{138}$. Co ważne, to jeden z dwóch listów, których kopię zachował dla siebie. Pisał w nim, odnosząc się m.in. do wydania swoich poezji wybranych w Polsce:

Myślałem, że Cię ucieszy powrót brata autentysty do czytelnika polskiego i to po 45 latach podczas których wpychano go w głąb pola zapomnienia. Autentyzm dlatego przetrwał, że miał kilku autorów o różnych a nie jednakowych, stylach mimo połączeń psychicznych, a te wyszły i z podłoża wiejskiego, i z pokolenia (tego pierwszego po odzyskanej niepodległości). Sądzę, że ktoś z tej grupy któremu los (Opatrzność) pozwoliła zrobić coś dla kultury polskiej w innym kraju i języku, będzie interesował badaczy literatury, szczególnie młodych, którzy nie zamykają się we własnym podwórku. Zawiść zawodowa tylko żółć zatruwa. Umniejszając drugich zawsze umniejszamy siebie.

Następnie odnosił się do zarzutów formułowanych przez Ożoga:

Mój zbiór esejów poprzez rewaluacje skrzywdzonych lub zapomnianych próbuje pokazać sens literatury polskiej w układzie porównawczym; upomina się o stare teksty, o średniowiecze, [Jana] Kochanowskiego i swoisty barok [Józefa Bartłomieja] Zimorowica - to jest ważne do pokazania na zewnątrz, nie tylko wałkowanie współczesności ze wszystkimi uproszczeniami, które potem trzeba przesiać przez bardziej zrównoważoną krytykę (bez perspektywy czasu i rewaluacji Norwid by dalej leżał we wspólnym grobie zapomnianych). Czy ty tego nie rozumiesz? Powtarzam, że w okresie kiedy byłeś niedoceniany, napisałem do ciebie epistołę, gdzie rozprawiłem się $\mathrm{z}$ oficjalnym niby-kultem ludowości przy jednoczesnym pomijaniu poetów naprawdę oryginalnych wywodzących się ze wsi - i tu była ocena twojego dorobku. List widać był tak dobry, że trafił do archiwów, a ty w rok potem dostałeś nagrodę. Pewnie przypadek lub figiel Opatrzności. Dalej nie chcesz zrozumieć znaczenia The Other Side of Silence, którą Oxford wydał - co, wolisz zdawkowe recenzje? — ta książka jest w bibliotekach uniwersyteckich, a rola autentyzmu jest pokazywana w kontekście, trzeba czytać ten rozdział razem $\mathrm{z}$ innymi, żeby pojąć istotę zagadnienia.

I wreszcie w zakończeniu listu wracał do sprawy korespondencji przedwojennej:

Mój Drogi, może i masz rację — te papierzyska korespondencji tylko szuflady zapeł-

mojej drodze. Wspomnienia, Kraków 1971; tegoż, Jak świętych obcowanie. Wspomnienia literackie, Warszawa 1978.

${ }^{137}$ J. B. Ożóg, Kartki z dzika różą, Warszawa 1987.

${ }^{138}$ List J. Pietrkiewicza do J. B. Ożoga z 18 września 1987. 
niają, spalić to wszystko, po co trzymać cudze bazgroły. Życzę ci jak najlepiej; nigdy cię niczym nie skrzywdziłem; wiem, że miałeś niełatwe życie i że wierny byłeś poezji — i jesteś. [...] Sursum corda, a pesar de todo, mimo wszystko.

Wyjaśnienia Pietrkiewicza - jak się można domyślać — chyba częściowo udobruchały Ożoga, który wysyłając w połowie grudnia 1987 roku kartkę świąteczną zaczął ją od słów „Mój Wielce Szanowny i Drogi!”, po czym donosił o przygotowywaniu do druku kolejnej książki, w której „Piszę o Tobie jak najlepiej”" ${ }^{139}$. Mimo to wieloletnia przyjaźń zbliżała się do kresu. W teczce korespondencji zachowanych w archiwum autora Prowincji znajduje się jeszcze jeden odpis (fragment) listu z grudnia 1988 roku. Czytamy w nim m.in.:

$\mathrm{W}$ jednym $\mathrm{z}$ ostatnich listów poczęstowałeś mnie szantażem jednego z tych, którzy nakładali pętlę stalinizmu na kulturę polską.

Wybaczam ci z serca, bo byłem i jestem lojalny wobec twojej poezji.

Ekologiczne protesty niczego nie dokonają, skoro ludzie nakładają sobie wzajemnie pętle winy. Jedno tylko ten nieszczęsny glob uleczy: Compassion i Caritas ${ }^{140}$.

W ten sposób, po pięćdziesięciu latach przyjaźni, dialog został przerwany. Na kolejne wznowienie go zabrakło czasu. Dwa i pół roku później Jan Bolesław Ożóg zmarł.

$* * *$

Zaprezentowana powyżej korespondencja Jerzego Pietrkiewicza i Jana Bolesława Ożoga pozwala na sformułowanie kilku wniosków.

Przede wszystkim należy stwierdzić, że przyjaźń łącząca obu poetów miała charakter głównie zawodowy, ściślej — literacko-poetycki. Korespondenci w zasadzie nie wychodzili w swoich listach poza problematykę poetycką, miejsca i roli ich twórczości w literackim pejzażu. Czując się zjednoczeni na płaszczyźnie autentyzmu, na nim koncentrowali dużą część swojej uwagi. Sprawy dodatkowe — problemy zdrowotne, sytuacja rodzinna i towarzyska - były zaledwie wzmiankowane, umieszczane w post scriptum, a przy tym dość często przez drugą stronę zupełnie ignorowane (np. informacje o życiu zawodowym syna Ożoga).

Omawiane listy dowodzą, że przyjaźń na odległość trwała, choć raczej trudno powiedzieć, że kwitła. W latach 1939-1991 obaj poeci spotkali się raz, podczas wizyty Pietrkiewicza w Polsce. Do zaplanowanej rewizyty Ożoga w Londynie nie doszło, zresztą - co krakowski poeta wyrzucał swojemu londyńskiemu towarzyszowi - ten drugi nie był wcale skłonny do pomocy w przygotowaniu tego spotkania. Pomimo tego, że zachowana korespondencja nie jest kompletna, widać też wyraźnie, że w pewnych okresach częstotliwość wymiany listów spadała, nieomal zamierała, aby po dwóch, trzech latach ponownie przybrać rysy regularności.

Co więcej, lektura tych listów dowodzi, że obu twórców łączyło coś więcej niż przynależność do jednej z grup poetyckich okresu dwudziestolecia międzywojennego. Obaj, rzecz jasna, trwali przy autentyzmie wiernie, choć trzeba oddać sprawiedliwość Ożogowi, że to jednak on był bardziej zaangażowanym wyznawcą i piewcą tego nurtu i że właściwie oceniał swoją rolę w jego promowaniu. Ale tych elementów spajających było więcej. Obaj pochodzili ze wsi i była ona ich arkadią, umiłowaną krainą, z której czerpali przez całe życie. Obaj przeszli drogę awansu społecznego, kończąc studia wyższe, co wszak nie było zjawiskiem powszechnym w odniesieniu do dzieci wywo-

${ }^{139}$ Karta pocztowa J. B. Ożoga do J. Pietrkiewicza z 17 grudnia 1987.

${ }^{140}$ Odpis fragmentu listu J. Pietrkiewicza do J. B. Ożoga z 1 grudnia 1988. 
dzących się ze wsi. U obu dostrzec można rysy prawicowo-nacjolnalistyczne ${ }^{141}$, objawiające się m.in. niechęcią do lewicy i antysemityzmem. I choć doświadczenie wojny zweryfikowało bardzo wyraźnie przede wszystkim drugą z tych postaw, to jednak ich echa odzywały się z rzadka także w powojennej korespondencji. Obaj wreszcie podporządkowali swoje życie literaturze nie tylko jako dziedzinie działalności artystycznej, ale także - choć w różnych formach - jako przedmiotowi opisu i badań. I choć ich drogi zawodowe ułożyły się ostatecznie inaczej (Pietrkiewicz — nauczyciel akademicki, Ożóg — zawodowy literat), a i wybór artystycznej drogi także był odmienny (Pietrkiewicz — proza w języku kraju osiedlenia, Ożóg — poezja tworzona w rodzimym języku), to jednak i tu można mówić o wspólnocie doświadczeń.

Co interesujące, choć obaj wielokrotnie zapewniali się o przyjaźni, to nie wiadomo, czy w zasadzie nie należałoby ich - do pewnego stopnia - uznać za konkurentów. Paradoks polegał bowiem na tym, że pisząc o autentyzmie, żaden nie mógł przemilczeć roli drugiego, a jednocześnie każdorazowo skrzętnie wykorzystywał taką okazję do budowania swojej literackiej pozycji. Zastanawiający jest fakt, że przez ponad czterdzieści lat Pietrkiewicz nie pomógł Ożogowi w znalezieniu thumacza jego utworów na język angielski. Z kolei Ożóg, pisząc kolejne książki o autentyzmie, obiecywał Pietrkiewiczowi, że w następnej z pewnością poświęci mu więcej miejsca i uwagi. Być może powodem tego stanu rzeczy był jeden, także wspólny obu pisarzom, niewykluczone, że właściwy wszystkim twórcom, rys osobowości. Chodzi o pewien rodzaj egocentryzmu, objawiający się głównie w - jak się wydaje - dość gorączkowym zabieganiu o uznanie, docenienie twórczości własnej, dokumentowanie wszystkich osiągnięć, omówień, recenzji czy choćby najdrobniejszych napomknięć, które miałyby stanowić potwierdzenie zasadności dokonanych wyborów artystycznej i zawodowej drogi.

\section{LITERATURA}

Adamczyk K., Doświadczenia polsko-żydowskie w literaturze emigracyjnej (1939-1980), Kraków 2008.

Andres Z., Świadek codzienności - Jerzy Pietrkiewicz, „Zeszyty Naukowe Uniwersytetu Rzeszowskiego. Seria Filologiczna. Historia Literatury” 2011, z. 70, s. 248-259.

Czernik S., Co i jak, „Okolica Poetów” 1936, nr 10, s. 2.

Czernik S., Fantazjotwórstwo poetyckie, „Okolica Poetów” 1935, nr 4/5, s. 2-5.

Czernik S., Okolica poetów. Wspomnienia i materiały, Poznań 1961.

Czernik S., Styl w liryce, „Okolica Poetów” 1935, nr 1, s. 3-6.

Jakitowicz M., Dopetnienie obrazu. Szkice o autentyzmie, Torun 1993.

Jerzy Pietrkiewicz. Inna wersja emigracji, red. B. Czarnecka, J. Kryszak, Torun 2000.

Koźniewski K., Historia co tydzień. Szkice o tygodnikach spoleczno-kulturalnych, Warszawa 1976.

„Kronika i różne”, „Oficyna Poetów” 1970, nr 18, s. 48.

Literatura polska XX wieku. Przewodnik encyklopedyczny, t. 1, red. A. Hutnikiewicz, A. Lam, Warszawa 2000.

Łobodowski J., Kilka słów o autentyzmie, „Wiadomości” 1981, nr 1 (1814), s. 20.

Moskalowa A., Autentyzm w polskiej poezji międzywojennej, Warszawa 1979.

Okolica poetów. Antologia poezji autentystów, oprac. A. Biskupski, Łódź 1978.

Okoliczanie. Antologia poezji polskiego autentyzmu, oprac. J. B. Ożóg, Warszawa 1984.

Ożóg J. B., Autentyzm, czy co innego?, „Oficyna Poetów” 1970, nr 17, s. 4.

Ożóg J. B., Chustka. Opowiadania, Warszawa 1959.

${ }^{141}$ Zob.: M. Jakitowicz, Chłopski nacjonalizm - Pietrkiewicz i Ożóg, [w:] tejże, Dopelnienie obrazu. Szkice o autentyzmie, Torun 1993. 
Ożóg J. B., Dzikie jabłka, Warszawa 1964.

Ożóg J. B., Jak świętych obcowanie. Wspomnienia literackie, Warszawa 1978.

Ożóg J. B., Kartki z dzika różą, Warszawa 1987.

Ożóg J. B., Mój autentyzm, Kraków 1975.

Ożóg J. B., Na mojej drodze. Wspomnienia, Kraków 1971.

Ożóg J. B., Popiół mirtowy i inne opowiadania, Warszawa 1963.

Ożóg J. B., Ucieczka, Lublin 1965.

Ożóg J. B., W dzień, gdy noc, Kraków 1963.

Ożóg J. B., Wierność sobie i ziemi. Szkice o autentyzmie, Kraków 1980.

Ożóg J. B., Wiersze wybrane, Warszawa 1957.

Ożóg J. B., Z manowców na prosta drogę, Łódź 1983.

Ożóg J. B., Zielony wiatr, Kraków 1958.

Peterekiewicz J., The other side of silence. The poet at the limits of language, London 1970.

Pietrkiewicz J., Dla pokrzepienia mózgów. Szkice literackie z lat 1940-1948. Nowoczesność w tradycji. Essay o poezji. Trust the trees, oprac. B. Czarnecka, Torun 2002.

Pietrkiewicz J., Druga strona milczenia. Poeta u krańców mowy, przeł. J. Jackowicz, Warszawa 2002.

Pietrkiewicz J., Gdy opadaja tuski ciała, przeł. A. Moskalowa, Warszawa 1986.

Pietrkiewicz J., Kula magiczna, Warszawa 1980.

Pietrkiewicz J., List o S[tanistawie] Czerniku, „Kultura” 1970, nr 3 (270), s. 134-135.

Pietrkiewicz J., Listy do redaktorów ,,Wiadomości”, oprac. i wstęp R. Moczkodan, Torun 2017.

Pietrkiewicz J., Literatura polska $w$ perspektywie europejskiej. Studia i rozprawy, przeł. A. Olszewska-Marcinkiewicz, I. Sieradzki, oprac. J. Starnawski, Warszawa 1986.

Pietrkiewicz J., Na szali Losu. Autobiografia, przeł. A. Skarbińska-Zielińska, Warszawa 2016.

Pietrkiewicz J., Po chłopsku. Powieść, t. 1-2, Londyn 1941.

Pietrkiewicz J., Poezja ułatwiona. K. Wierzyńskiemu w odpowiedzi, „Myśl Polska” 1943, nr 58.

Pietrkiewicz J., Poezje wybrane, posł. A. Moskalowa, Warszawa 1986.

Pietrkiewicz J., Pogrzeb Europy. Liryki. Poematy. Essay o poezji, Londyn 1946.

Pietrkiewicz J., Prowincja. Poemat, Warszawa 1936.

Pietrkiewicz J., Ultraista Borges z Argentyny, „Myśl Polska” 1948, nr 122.

Pietrkiewicz J., Umarli nie sa bezbronni. Opowiadania z życia pod okupacja niemiecka, Glasgow 1943.

Pietrkiewicz J., Wiersze i poematy, Warszawa 1938.

Szarek M., Wiersze i proza, oprac. J. B. Ożóg, Warszawa 1956.

Taborski B., Poeta u krańców języka, „Oficyna Poetów” 1970, nr 17, s. 18-20.

Zygma Z., Strofy do czytania, „Wiadomości” 1958, nr 25 (638), s. 10.

\section{JERZY PIETRKIEWICZ AND JAN BOLESŁAW OŻÓG: AN EPISTOLARY DIALOGUE OF TWO 'AUTHENTIC' POETS (1937-1988)}

The article explores the relationship between Jerzy Pietrkiewicz and Jan Bolesław Ożóg. It is based on the examination of a collection of letters kept at the Jagiellonian Library in Cracow and the Archives of Polish Emigration in Torun. The two poets met before the Second World War as members of a literary group of 'authentic' poets. After the war Pietrkiewicz settled in England and Ożóg remained in Poland. Their friendship continued in the letters they exchanged. The article analyses the themes and problems which they discussed in their letters, in particular the promotion of 'authentic' poetry.

KEY WORDS: authentic poetry, $20^{\text {th }}$-century Polish poetry, correspondence

SŁOWA KLUCZOWE: Autentyzm, poezja polska XX wieku, korespondencja 